\title{
Direct Innervation of GnRH Neurons by Metabolic- and Sexual Odorant-Sensing Leptin Receptor Neurons in the Hypothalamic Ventral Premammillary Nucleus
}

\author{
Rebecca L. Leshan, ${ }^{1,2}$ Gwendolyn W. Louis, ${ }^{1,2}$ Young-Hwan Jo, ${ }^{3}$ Christopher J. Rhodes, ${ }^{4}$ Heike Münzberg, ${ }^{1}$ and \\ Martin G. Myers Jri ${ }^{1,2}$ \\ ${ }^{1}$ Division of Metabolism, Endocrinology, and Diabetes, Department of Internal Medicine and 2Department of Molecular and Integrative Physiology, \\ University of Michigan, Ann Arbor, Michigan 48109, ${ }^{3}$ Division of Endocrinology, Department of Medicine, Albert Einstein College of Medicine, Bronx, New \\ York 10461, and ${ }^{4}$ Kovler Diabetes Center, University of Chicago, Chicago, Illinois 60637
}

Leptin acts via its receptor (LepRb) on specific CNS neurons to signal the adequacy of long-term energy stores, thereby permitting the expenditure of resources on energy-intensive processes such as reproduction. The ventral premammillary nucleus of the hypothalamus $(\mathrm{PMv})$, which has been implicated in the stimulation of gonadotropin release by olfactory cues, contains numerous LepRb neurons, suggesting a potential role for LepRb PMv neurons in transmitting both metabolic and odorant signals to the neuroendocrine reproductive system. Indeed, Fos immunoreactivity and electrophysiologic recordings revealed the direct activation of LepRb PMv neurons by leptin, and exposure to odors from mice of the opposite sex promoted Fos immunoreactivity (Fos-IR) in many LepRb PMv neurons. To determine the regions innervated by the LepRb PMv neurons, we used two novel cre-activated tract-tracing systems in Lepr ${ }^{c r e}$ animals; data from these systems and from standard tracing techniques revealed that LepRb PMv neurons project to a subset of the regions, including the preoptic area, that are innervated by the PMv as a whole. Furthermore, the retrograde accumulation in LepRb PMv neurons of a trans-synaptic tracer from GnRH neurons revealed the direct innervation of GnRH neurons by many LepRb PMv neurons. Thus, LepRb PMv neurons sense metabolic and sexual odorant cues and project to the rostral hypothalamus to directly innervate $\mathrm{GnRH}$ neurons. These results are consistent with a role for LepRb PMv neurons in regulating the reproductive axis in response to metabolic and odorant stimuli.

\section{Introduction}

Appropriate energy balance governs reproductive competency: Inadequate adiposity attenuates the activity of the reproductive axis, resulting in anovulation in females (De Souza et al., 1998). Thus, a strong and precise signaling mechanism must link energy homeostasis with reproduction. The adipocyte-derived hormone, leptin, circulates in approximate proportion to fat stores to signal long-term energy status (Friedman, 2002; Myers, 2004; Elmquist et al., 2005; Morton et al., 2006; Berthoud, 2007; Gao and Horvath, 2007). In addition to attenuating feeding, leptin permits energy expenditure and activates the neuroendocrine reproductive axis: Adequate leptin levels enable the onset of puberty, whereas the lack of leptin in rodents or humans with genetic leptin deficiency or lipodystrophy results in hypothalamic

Received Jan. 12, 2009; revised Feb. 11, 2009; accepted Feb. 11, 2009.

This work was supported by National Institutes of Health (NIH) Grants R01 DK057768 and DK078056 (to M.G.M.), grants from the American Heart Association (to M.G.M. and R.L.L.), the Reproductive Studies Program training grant at the University of Michigan (NIHT32 HD7048; to R.L.L. and G.W.L.), and the Cellular and Molecular Biology Core of the Michigan Diabetes Research and Training Center (NIH DK020572) and the University of Michigan Cancer Center (NIH CA46592).

Correspondence should be addressed to Dr. Martin G. Myers Jr, Division of Metabolism, Endocrinology, and Diabetes, Department of Medicine, University of Michigan Medical School, 5560 MSRB II/0678, 1150 West Medical Center Drive, Ann Arbor, MI 48109. E-mail: mgmyers@umich.edu.

DOI:10.1523/JNEUROSCI.0155-09.2009

Copyright $\odot 2009$ Society for Neuroscience $\quad 0270-6474 / 09 / 293138-10 \$ 15.00 / 0$ amenorrhea that is reversible with leptin replacement (Ahima et al., 1996, 1997; Chehab et al., 1996; Farooqi et al., 1999; Shimomura et al., 1999; Oral et al., 2002). Similarly, food restriction, which decreases circulating leptin levels, inhibits the reproductive axis (Marsteller and Lynch, 1987; Ahima et al., 1996). Leptin reverses much of this effect on food-restricted rodents, partially restoring testosterone (males), and improving luteinizing hormone (LH) levels and cyclicity (females) in mice (Ahima et al., 1996), as well as maintaining LH pulse frequency, sexual maturation, estrus cycling, ovulation and sexual behaviors in a variety of rodent models (Gruaz et al., 1998; Nagatani et al., 1998; Schneider et al., 1998; Sullivan et al., 2002). Thus, leptin represents a crucial metabolic signal to the reproductive axis.

Whereas alternative splicing of a single leptin receptor gene (Lepr) produces multiple LepR isoforms, only the long (LepRb) isoform mediates intracellular signaling and is required for leptin action in vivo, and LepRb expression in the brain is sufficient to mediate most leptin effects, including reproduction (Cohen et al., 2001; de Luca et al., 2005). Also, whereas GnRH neurons do not contain LepRb, intracerebroventricular leptin stimulates LH release and activates the reproductive axis, suggesting that leptin acts indirectly on the reproductive system, via neurons that synapse on GnRH neurons (Nagatani et al., 1998; Gonzalez et al., 1999; Burcelin et al., 2003).

Several brain areas involved in energy homeostasis contain 
large populations of LepRb-expressing neurons, including hypothalamic regions such as the lateral hypothalamus (LHA) and the arcuate (ARC), ventromedial (VMH), and ventral premammillary (PMv) nuclei (Elmquist et al., 1998; Leshan et al., 2006). Whereas most attention has focused on the ARC LepRb neurons, the PMv exhibits substantial LepRb mRNA expression and responds to peripheral leptin administration (Elmquist et al., 1997, 1998; Elias et al., 2000).

Although LepRb PMv neurons have not been specifically examined, a variety of data suggest a role in reproduction for at least some PMv neurons. The PMv is reciprocally connected with regions central to the regulation of reproduction, including the preoptic nuclei (POA) and anteroventral periventricular nucleus $(\mathrm{AvPv})$, and with parts of the vomeronasal olfactory system, such as the bed nucleus of the stria terminalis (BST) and amygdala (Canteras et al., 1992, 1995; Li et al., 2002; Rondini et al., 2004; Cavalcante et al., 2006b; Hahn and Coen, 2006). Indeed, stimulation with estrogen or progesterone or mating activate substantial numbers of PMv neurons, as does the exposure of rodents to bedding soiled by animals of the opposite sex (Kollack-Walker and Newman, 1995; Coolen et al., 1996; Yokosuka et al., 1999; Cavalcante et al., 2006a). Unilateral lesions of the PMv in the male rat block the ability of ipsilateral medial amygdala (MeA) stimulation to elicit an increase in $\mathrm{LH}$, placing the PMv between the MeA and the rostral hypothalamic control of neuroendocrine reproductive function in a putative circuit beginning with sexual odorants and ending in rise of serum LH (Beltramino and Taleisnik, 1985).

Given the placement of the PMv within this olfactory $\rightarrow$ reproductive circuit and the large population of LepRb neurons in this nucleus, we hypothesized that LepRb PMv neurons might sense both leptin and sexual odorant cues and communicate this information to the reproductive system by directly innervating rostral hypothalamic GnRH neurons.

\section{Materials and Methods}

Materials. Recombinant mouse leptin was obtained from the National Hormone and Peptide Program (Dr. A. F. Parlow, Los Angeles, CA). Fluorogold-equivalent, hydroxystilbamidine, was purchased from Biotium. Rabbit anti-pSTAT3 was from Cell Signaling Technologies, rabbit anti-cFos was from Calbiochem (EMD Biosciences/Merck), mouse antiNeuN (clone A60) and rabbit anti-Fluorogold were from Millipore Bioscience Research Reagents, and rabbit anti-nNOS was from ImmunoStar. Rabbit anti-wheat germ agglutinin (WGA; used to detect barley lectin) was from Sigma-Aldrich, and chicken anti-EGFP was from Abcam. Normal donkey serum (NDS) and biotinylated donkey anti-rabbit were purchased from Jackson ImmunoResearch. Alexa 488-conjugated donkey anti-rabbit, Alexa 488-conjugated goat anti-chicken, and Alexa 568-conjugated goat anti-rabbit were purchased from Invitrogen. ABC Vectastain Elite kit was purchased from Vector Laboratories. All other immunohistochemical supplies were purchased from Sigma-Aldrich.

Animals. All mice were bred in our colony in the Unit for Laboratory Animal Medicine at the University of Michigan. All animals and procedures used were in accordance with the guidelines and approval of the University Committee on the Care and Use of Animals. C57BL/6J mice were purchased from The Jackson Laboratory. Animals were given ad libitum access to food and water, and were housed in groups of 2-4, except where indicated.

We previously generated mice that contain an internal ribosomal entry site (IRES)-driven second cistron encoding cre recombinase "knocked in" to the 3'-UTR of the LepRb-specific exon of Lepr (Leshan et al., 2006). Hence, in Lepr ${ }^{\text {cre }}$ mice, the cre coding sequence is part of the LepRbspecific mRNA such that its expression is restricted to LepRb-expressing neurons. To reliably identify LepRb-expressing neurons, we crossed the Lepr ${ }^{\text {Cre }}$ mice with Gt(ROSA)26Sor ${ }^{\text {tm2Sho }}\left(\right.$ ROSA $\left.^{E G F P}\right)$ mice from The
Jackson Laboratory. This line has been engineered such that cremediated deletion of a floxed transcription-blocking Neo cassette results in the expression of enhanced green fluorescent protein (EGFP) from the ubiquitously expressed ROSA26 locus (Mao et al., 1999). Because IRESmediated cre expression is modest, both alleles were bred to homozygos-

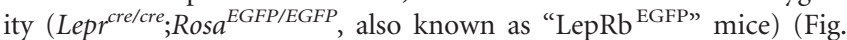
$1 A)$ to enhance the detection of LepRb neurons by EGFP expression.

To generate the Gt(ROSA)26Sor ${ }^{\text {EGFP }}$ (Rosa ${ }^{\text {EGFPf }}$ ) animals, we obtained and used the pBigT/pROSA26PA targeting system from Dr. Frank Costantini (Columbia University) (Srinivas et al., 2001) and inserted the sequences for EGFPf in the targeting system for electroporation into R1 ES cells in the University of Michigan Transgenic Animal Model Core. Clones were initially screened by quantitative PCR functional loss of homozygosity assays, as described previously (Soliman et al., 2007), and confirmed by Southern blotting. Positive clones were injected into C57 blastocysts for chimera generation and germline (brown) progeny from the chimeras were screened for the presence of EGFP. Germline progeny containing the targeted allele were bred with LepRb ${ }^{\text {cre }}$ animals to generate Lepr $^{\text {crel+ }} ; R_{\text {OSA }}{ }^{\text {EGPPf }}\left(\right.$ LepRb $\left.{ }^{\text {EGFPf }}\right)$ animals (Fig. $1 A$ ).

The previously described "BIG" mice (Boehm et al., 2005) were generously provided by Drs. Linda Buck and Ulrich Boehm and were propagated in our colony.

Perfusion and immunolabeling. Mice were injected intraperitoneally with leptin $(5.0 \mathrm{mg} / \mathrm{kg}$ body weight) or equal volume vehicle (PBS, $\mathrm{pH}$ 7.4) where indicated, and were anesthetized $2-4 \mathrm{~h}$ later (as indicated) with intraperitoneal sodium pentobarbital (150 mg/kg). Leptin and PBS administration was arranged such that all perfusions were performed during late afternoon, between 3:00 and 5:00 P.M., just before the onset of the dark cycle. Transcardiac perfusion with PBS followed by $4 \%$ paraformaldehyde, removal of brains, postfixation, and cryoprotection were performed as described (Münzberg et al., 2003). Brains were sectioned in $30 \mu \mathrm{m}$ coronal sections, collected in four representative series, and stored at $-20^{\circ} \mathrm{C}$ until use. For immunofluorescent (IF) labeling, free-floating brain sections were blocked in NDS and then incubated with primary antibodies (anti-EGFP, 1:1000; anti-Fluorogold, 1:3000; anti-cFos, 1:40,000; anti-pSTAT3, 1:500; anti-NOS1, 1:1000). Sections were washed and incubated with Alexa-conjugated secondary antibodies (1:200). For immunohistochemical labeling (IHC) of pSTAT3 or Fos, sections were pretreated sequentially in $1 \% \mathrm{H}_{2} \mathrm{O}_{2} / 1 \% \mathrm{NaOH}, 0.3 \%$ glycine, and $0.3 \%$ SDS, then blocked in NDS and incubated in primary antibodies (antipSTAT3, 1:500; anti-cFos, 1:40,000). Sections were washed, incubated in biotinylated donkey anti-rabbit $(1: 1000)$, followed by avidin-biotincomplex labeling. Signals were developed with diaminobenzidine resulting in a brown precipitate. After washing, brains continued to IF for additional labeling. For both IF and IHC, sections were mounted onto Superfrost Plus slides (Fisher Scientific) and coverslipped with ProLong Antifade mounting medium (Invitrogen).

Intracerebral injections. For the intracerebral administration of tracers, animals were anesthetized with isoflurane and placed in a stereotaxic frame (Kopf Instruments). The skull was exposed and coordinates for bregma were recorded. To these measures were added: $-2.3 \mathrm{~mm}$ posterior $(\mathrm{A} / \mathrm{P})$ to bregma, $-0.4 \mathrm{~mm}$ lateral to midline $(\mathrm{M} / \mathrm{L}),-5.6 \mathrm{~mm}$ ventral to dura $(\mathrm{D} / \mathrm{V})$ for $\mathrm{PMv} ;+0.4 \mathrm{~mm} \mathrm{~A} / \mathrm{P},-0.4 \mathrm{~mm} \mathrm{M} / \mathrm{L},-4.45 \mathrm{~mm}$ $\mathrm{D} / \mathrm{V}$ for POA; and $-1.55 \mathrm{~mm} \mathrm{~A} / \mathrm{P},-1.85 \mathrm{~mm} \mathrm{M} / \mathrm{L},-5.2 \mathrm{~mm} \mathrm{D} / \mathrm{V}$ for MeA. A stainless steel guide cannula with dummy (Plastics One) was lowered to the appropriate depth.

We modified pShuttle (He et al., 1998) to generate an adenoviral transfer vector containing the CMV promoter upstream of a transcriptionblocking cassette followed by sequences encoding farnesylated EGFP (EGFPf) to generate Ad-iZ/EGFPf (Fig. 1A), which mediates the expression of EGFPf only when transduced into cre-expressing cells. Adenoviral stocks were prepared as described previously (Gelling et al., 2006). For injections of Ad-iZ/EGFPf to Lepr ${ }^{\text {cre/cre }}$ mice, cannulae were placed at $\mathrm{PMv}$ coordinates and $250 \mathrm{nl}$ from a $5.1 \times 10^{11} \mathrm{pfu} / \mathrm{ml}$ stock was injected over $5 \mathrm{~min}$. After an additional $10 \mathrm{~min}$, the injector was removed, the hole filled with bone wax (Ethicon) and skin closed with sutures. Animals were allowed to recover on a heating pad and then single-housed in a biohazard containment room. Five days after injection, animals were perfused as described. 
For injections of the retrograde tracer, Fluorogold-equivalent, hydroxystilbamidine (FG), cannulae were placed at POA coordinates of $\mathrm{C} 57 \mathrm{BL} / 6 \mathrm{~J}$ mice, or MeA coordinates of LepRb ${ }^{\text {GFP }}$ mice and $10 \mathrm{nl}$ of a $2 \%$ FG solution was injected over $30 \mathrm{~s}$. Ten minutes later, the injector was removed, the hole filled with bone wax and skin closed with sutures. Animals were allowed to recover on a heating pad and then single-housed in clean cages. Four days after injection, animals were perfused and brains were removed as described. POA-injected C57BL/6J animals received $5 \mathrm{mg} / \mathrm{kg}$ i.p. leptin $2 \mathrm{~h}$ before perfusion.

Electrophysiological slice preparation. Transverse brain slices were prepared from mice at postnatal age 21-28. Similar responses to leptin were observed in animals independent of age between 21 and 28 d. Animals were anesthetized with a mixture of ketamine and xylazine. After decapitation, the brain was transferred into a sucrose-based solution bubbled with $95 \% \mathrm{O}_{2}-5 \% \mathrm{CO}_{2}$ and maintained at $\sim 3^{\circ} \mathrm{C}$. This solution contained the following (in $\mathrm{mM}$ ): 248 sucrose, $2 \mathrm{KCl}, 1 \mathrm{MgCl}_{2}, 1.25 \mathrm{KH}_{2} \mathrm{PO}_{4}, 26$ $\mathrm{NaHCO}_{3}$, and 10 glucose. Transverse coronal brain slices $(200 \mu \mathrm{M})$ were prepared using a Vibratome (Leica VT1000S). Slices were equilibrated with an oxygenated artificial CSF (aCSF) for $>1$ h before transfer to the recording chamber. The slices were continuously superfused with aCSF at a rate of $2 \mathrm{ml} / \mathrm{min}$ containing the following (in $\mathrm{mm}$ ): $113 \mathrm{NaCl}, 3 \mathrm{KCl}, 1$ $\mathrm{NaH}_{2} \mathrm{PO}_{4}, 26 \mathrm{NaHCO}_{3}, 2.5 \mathrm{CaCl}_{2}, 1 \mathrm{MgCl}_{2}$, and 5 glucose in $95 \% \mathrm{O}_{2} / 5 \% \mathrm{CO}_{2}$ at room temperature.

Electrophysiological recordings. Brain slices were placed on the stage of an upright, infrareddifferential interference contrast microscope (Olympus BX50WI) mounted on a Gibraltar $\mathrm{X}$-Y table (Burleigh) and visualized with a $40 \mathrm{X}$ water-immersion objective by infrared microscopy (DAGE MTI camera). Membrane potentials were recorded at room temperature $\left(25-26^{\circ} \mathrm{C}\right)$ to a $\mathrm{PC}$ after being filtered at $10 \mathrm{kHz}$ by a Multiclamp $700 \mathrm{~B}$ and analyzed using pClamp10 (Axon). The external solution contained the following (in mM): $113 \mathrm{NaCl}, 3 \mathrm{KCl}, 1$ $\mathrm{NaH}_{2} \mathrm{PO}_{4}, 26 \mathrm{NaHCO}_{3}, 2.5 \mathrm{CaCl}_{2}, 1 \mathrm{MgCl}_{2}$, and 5 glucose in $95 \% \mathrm{O}_{2} / 5 \% \mathrm{CO}_{2}$. CNQX (10 $\mu \mathrm{M})$, DL-amino-phosphonovaleric acid (DLAP-5, $50 \mu \mathrm{M})$, picrotoxin $(100 \mu \mathrm{M})$ and strychnine $(1 \mu \mathrm{M})$ were continuously present in the external solution to block synaptic inputs. The internal solution contained the following (in $\mathrm{mm}): 115 \mathrm{~K}$-acetate, $10 \mathrm{KCl}, 2 \mathrm{MgCl}_{2}, 10$ EGTA,

10 HEPES, $2 \mathrm{Na}_{2} \mathrm{ATP}, 0.5 \mathrm{Na}_{2} \mathrm{GTP}$, and 5 phosphocreatine. Pipette resistance ranged from 3 to $4 \mathrm{M} \Omega$.

The effect of leptin compared with control was analyzed using Student's $t$ test (Origin 7.0). Responding neurons were divided from nonresponding neurons based on the criterion that the change in membrane potential induced by application of leptin was \pm 3 times the SD before treatment with leptin, as described in recent studies (Cowley et al., 2001; Dhillon et al., 2006; Hommel et al., 2006; Smith et al., 2007). Data were considered significantly different for $p<0.05$. All statistical results are given as mean \pm SEM.

Soiled bedding experiments. On day 0 , adult male and female LepRb ${ }^{\text {GFP }}$ mice were single-housed and designated to one of two groups: "fresh" bedding ( $n=4$ males, 3 females), or "soiled" bedding ( $n=5$ males, 3
(LepRb Neurons Only)
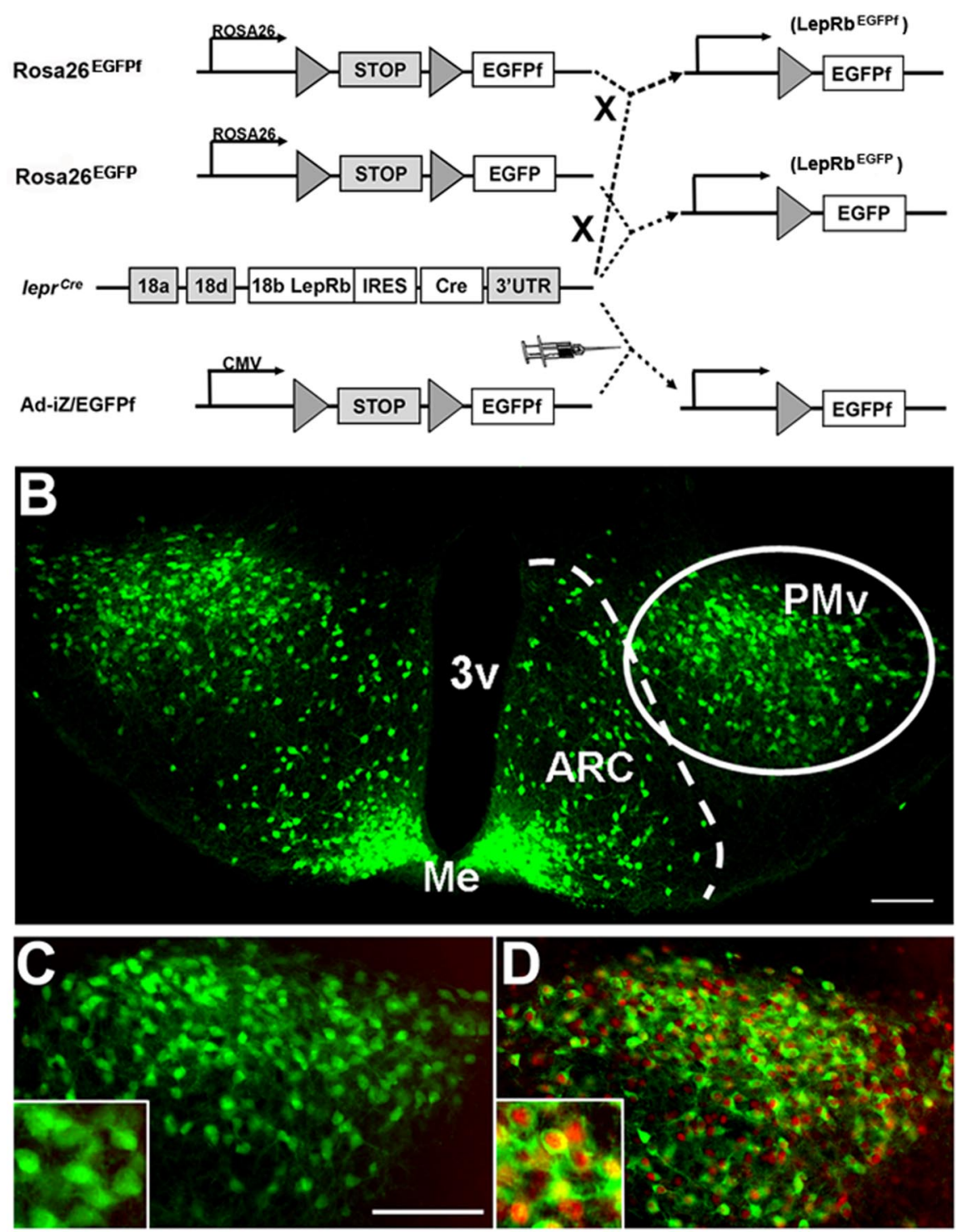

Figure 1. Lepr ${ }^{\text {cre }}$ mice and cre-inducible systems to interrogate LepRb neurons. $A$, The coding sequence of Cre recombinase was targeted into the LepRb-specific exon in the lepr gene (lepr ${ }^{\text {cre }}$ mice). Lepr ${ }^{\text {rre }}$ mice were mated with Rosa ${ }^{\text {EGPP }}$ mice, Rosa ${ }^{\text {EGPP }}$ mice, or injected with Ad-iZ/EGFPf. In each case a floxed transcription blocker precedes reporter gene sequences (EGFP or EGFPf) and cre-mediated excision of the transcription blocker results in EGFP or EGFPf expression in cells expressing cre/LepRb. $\boldsymbol{B}-\boldsymbol{D}$, LepRb ${ }^{\text {GGP }}$ mice, homozygous for lepr ${ }^{\text {re }}$ and Rosa ${ }^{\text {EGFP }}$, exhibit a substantial population of EGFP-positive (green, cytoplasmic) cells in the PMv. Systemic leptin administration (5 mg/kg i.p., $2 \mathrm{~h}$ ) of LepRb ${ }^{\mathrm{EGFP}}$ mice induces phosphorylation of STAT3 (pSTAT3; red nuclear) in $96 \pm 0.2 \%(n=3)$ of EGFP-positive (LepRb) cells (D). High magnification insets show colocalization of cytoplasmic EGFP and nuclear PSTAT3. Scale bars: $100 \mu \mathrm{m}$. 3v, third cerebral ventricle; Me, median eminence.

females). On day 6, animals were brought to the lab to acclimate overnight. The following day, day 7 , animals in the fresh group were moved to cages containing fresh bedding, whereas animals in the soiled group were moved to cages which had previously individually housed a mouse of the opposite sex for $7 \mathrm{~d}$. After $90 \mathrm{~min}$ of exposure, animals were perfused as described above.

Microscopy and image analysis. Microscopic images were obtained using an Olympus BX-51 brightfield microscope with DP30BW camera (Olympus). For quantification of EGFP/pSTAT3-IR or EGFP/Fos-IR double-labeled neurons, pictures of the identical areas were taken on channels for Alexa 488 (EGFP), Alexa 568 (cFos), or brightfield (pSTAT3, cFos). Using Adobe Photoshop software (Adobe Systems), the brightfield channel was inverted (except in Fig. 6C) and false-colored red. Both channels (red and green) were merged in a red-green picture, and 

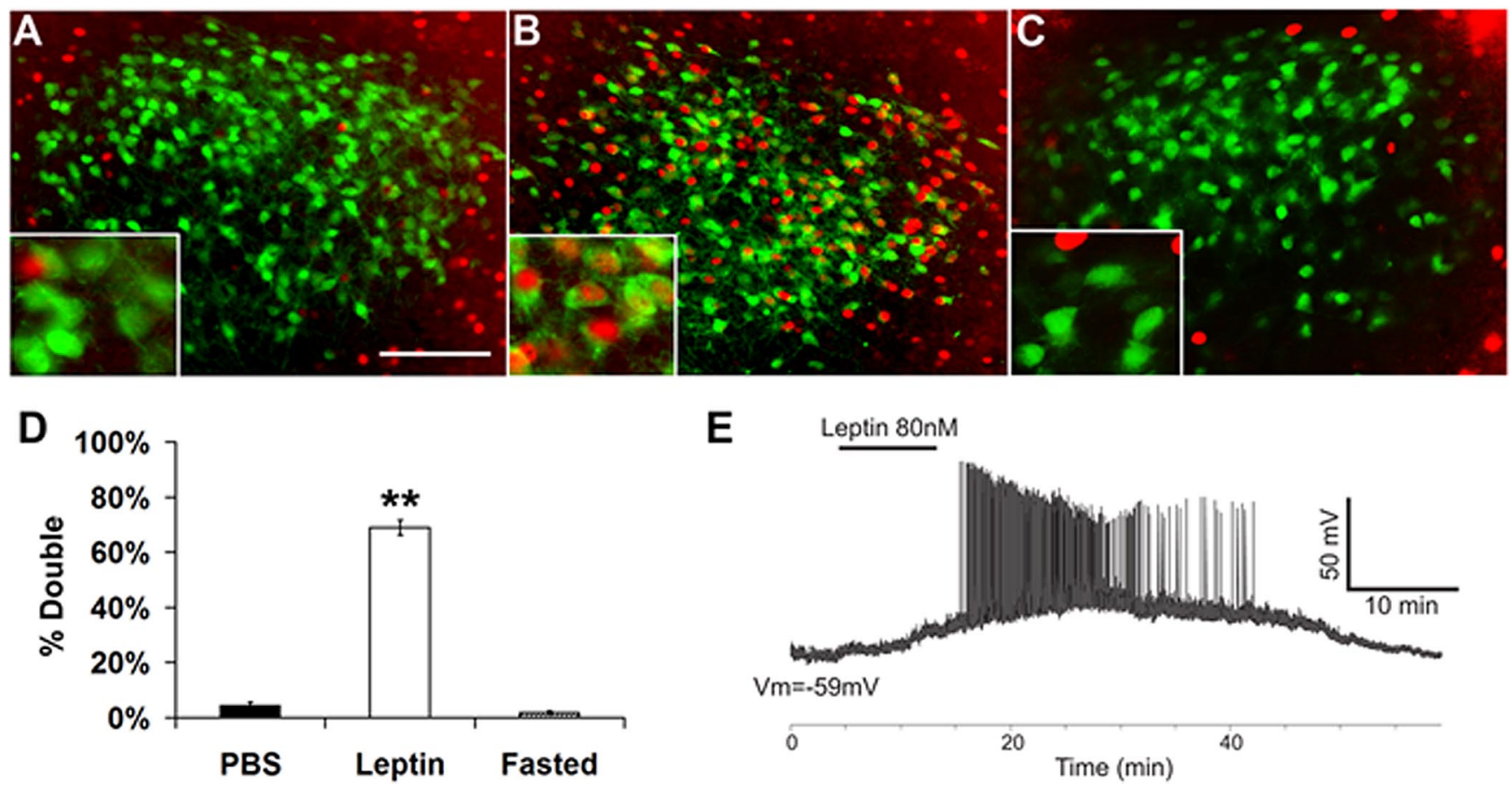

Figure 2. $\boldsymbol{A}-\boldsymbol{E}$, Regulation of LepRb PMv neuronal activity by leptin in LepRb EGFP mice. EGFP-containing LepRb neurons in the PMv of LepRb ${ }^{\text {EGFP }}$ mice showed increased cFos immunoreactivity (Fos-IR) in response to leptin $(\boldsymbol{B})(5 \mathrm{mg} / \mathrm{kg}$ i.p., $4 \mathrm{~h}$ ), but not PBS $(\boldsymbol{A})$, or fasting ( $\boldsymbol{C}$. High magnification insets show colocalization of GFP ( green, cytoplasmic) and Fos-IR (red, nuclear). Quantification reveals a significant increase in percentage EGFP-positive cells with Fos-IR nuclei after leptin treatment compared with either PBS-treated or fasted groups (D).E, Whole-cell patch-clamp recordings from EGFP-identified LepRb PMv neurons from LepRb ${ }^{\text {EGPP }}$ mice in current clamp mode (synaptic inputs blocked). Treatment with leptin depolarized LepRb neurons in $67 \%$ of the neurons tested (control: $-65 \pm 4 \mathrm{mV}$, plus leptin: $-54 \pm 5 \mathrm{mV} ; n=8$ of 12 neurons). ${ }^{* *} p<0.01$. Scale bar: $100 \mu \mathrm{m}$.

single- and double-labeled neurons were counted and recorded. [Immunolabeling of nitric oxide synthase-1 (NOS1) was used to define boundaries of the PMv for counting (supplemental Fig. S1, available at www. jneurosci.org as supplemental material)]. Values are presented as mean \pm SEM, and differences analyzed by Student's $t$ test, or by one-way ANOVA followed by Tukey post-test, as indicated in the text. Differences were deemed significant for $p<0.05$.

\section{Results}

LepRb ${ }^{\text {EGFP }}$ Mice reveal PMv LepRb neurons for study

Reliable detection of LepRb protein in the mouse brain using LepR-specific antibodies remains problematic, presumably because of the relatively low expression of LepRb even in neurons that express the receptor at functional levels. Furthermore, functional assays of LepRb expression, although robust and facile, require prior leptin treatment. Furthermore, neither these methods nor in situ hybridization histochemistry permits the identification of LepRb neurons before their electrophysiological examination. To facilitate the detection and study of LepRb neurons throughout the brain, we thus generated mice expressing enhanced green fluorescent protein (EGFP) in LepRb-expressing

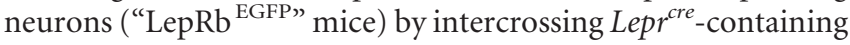
mice with mice containing a cre-inducible EGFP reporter allele, as described in Materials and Methods (Fig. 1A).

Immunofluorescent detection of EGFP-IR in LepRb ${ }^{\text {EGFP }}$ mice revealed EGFP immunoreactivity (EGFP-IR) in a population of cells in the PMv (Fig. 1 B), consistent with previous studies demonstrating LepRb neurons in this area (Elmquist et al., 1998; Leshan et al., 2006). Expression in other hypothalamic nuclei such as VMH and DMH was observed, although distinct from the PMv subpopulation (supplemental Fig. 2, available at www. jneurosci.org as supplemental material). We found similar numbers of EGFP-IR cells in the PMv and the ARC (PMv: $4830 \pm 200$ per brain; $n=3$; ARC: $4320 \pm 330$ per brain; $n=3$ ). No genderspecific differences in cell number were observed for either of these nuclei (data not shown). The well known role of ARC LepRb neurons to leptin action (Friedman, 2002; Myers, 2004; Elmquist et al., 2005; Morton et al., 2006; Berthoud, 2007; Gao and Horvath, 2007) and the similar size of the ARC and PMv LepRb populations suggest the importance of LepRb PMv neurons to leptin action.

Activation of LepRb recruits STAT3 directly to the receptor to mediate STAT3 tyrosine phosphorylation (pSTAT3) (White et al., 1997; Banks et al., 2000). Although other growth factors and cytokines also regulate the phosphorylation of STAT3, the general level of immunohistochemically (IHC)detectable pSTAT3 in the brain is low in the absence of leptin treatment, and the increase in pSTAT3-IR after leptin stimulation sensitively and reliably reveals cell-autonomous leptin action to identify neurons that express functional LepRb (Münzberg et al., 2003). To confirm the expression of functional LepRb in the EGFP-containing PMv neurons in LepRb ${ }^{\text {EGFP }}$ mice, we thus examined the colocalization of pSTAT3-IR with EGFP-IR in LepRb ${ }^{\text {EGFP }}$ mice after treatment with vehicle or leptin (Fig. $1 C, D)$. Although only $1 \pm 0.2 \%(n=4)$ of EGFP-IR PMv cells contained IHC-detectable pSTAT3 in controls, $96 \pm 0.2 \%(n=3)$ of EGFP-IR neurons contained pSTAT3-IR in leptin-treated animals. Thus, EGFP-containing PMv neurons in LepRb $^{\text {EGFP }}$ mice possess functional LepRb.

Colocalization of EGFP-IR in the PMv of LepRb ${ }^{\text {EGFP }}$ mice with the neuronal marker NeuN revealed that these LepRb PMv neurons comprise $44.6 \pm 3.3 \%(n=3)$ of the total number of PMv neurons (data not shown); LepRb PMv neurons thus represent a subpopulation of the larger set of $\mathrm{PMv}$ neurons. 


\section{Direct activation of PMv LepRb neurons by leptin}

Within the ARC, the best-characterized site of leptin action, two distinct neuronal populations each express LepRb, but exhibit opposite electrical responses to leptin: leptin hyperpolarizes/inhibits neurons that express agouti related peptide (AgRP), but depolarizes those that express pro-opiomelanocortin (POMC) (Elias et al., 1999; Elmquist et al., 1999; Schwartz et al., 2000). To understand whether leptin activates or inhibits LepRb PMv neurons, we used Fos-IR as an IHC marker of neuronal activity in EGFP-IR PMv neurons in ad libitum-fed LepRb ${ }^{\text {EGFP }}$ mice treated for $4 \mathrm{~h}$ with leptin or vehicle, or with vehicle after a $24 \mathrm{~h}$ fast (Fig. $2 A-D)$. This analysis revealed that leptin stimulated the accumulation of Fos-IR in the majority of LepRb PMv neurons (Fed/PBS, $4 \pm 2 \%$; leptin, $69 \pm 2 \% ; n=3$ each condition; $p<0.01$ by ANOVA followed by Tukey post-test). In contrast to the ARC, in which fasting activates a population of EGFP-IR/LepRb neurons (supplemental Fig. 3, available at www.jneurosci.org as supplemental material), fasting tended to reduce Fos-IR in the PMv (Fasted, $2 \pm 1 \% ; p=$ n.s.).

Although the preceding data reveal that leptin action depolarizes LepRb PMv neurons, they do not rule out potential indirect actions of leptin on these neurons, as via the regulation of classical neurotransmitter release from other LepRb neurons. We thus examined the activity of LepRb PMv cells in acute slice preparations from hypothalami of LepRb ${ }^{\text {EGFP }}$ mice using whole-cell patch-clamp recordings from EGFP-identified neurons in the PMv (Fig. 2E). We measured the membrane potential of these cells in current clamp mode under conditions in which synaptic inputs from glutamate, GABA and glycine were blocked (see Materials and Methods). Treatment with leptin depolarized $\sim 67 \%$ of the LepRb PMv neurons tested (control: $-65 \pm 4 \mathrm{mV}$, plus leptin: $-54 \pm 5 \mathrm{mV} ; p<0.05 ; n=8$ of 12 neurons). The onset varied from $\sim 60$ to $\sim 320$ s after application of leptin (the mean onset time: $150 \pm 35 s ; n=8$ ), and the mean change in membrane potential was $11.1 \pm 2 \mathrm{mV}$. Although some LepRb PMv neurons exhibited no significant response to leptin (control: n-69.6 \pm 7 $\mathrm{mV}$ vs leptin: $-69.7 \pm 8 \mathrm{mV} ; n=4$ ), none were hyperpolarized by leptin. Thus, leptin acutely depolarizes LepRb PMv neurons independently of the presynaptic release of these amino acid neurotransmitters.

The finding that a similar percentage of neurons were depolarized by leptin in electrophysiologic studies in slice preparations and by the criterion of Fos-IR in vivo suggests that age and reproductive status do not affect the ability of leptin to activate LepRb PMv neurons, as well as suggesting the direct and physiologic activation of the majority of LepRb PMv neurons by leptin. The uniformly high percentage of LepRb PMv neurons activated by leptin, and the absence of any leptin-stimulated hyperpolarization or fasting-mediated increased Fos-IR in these neurons further suggests that, in contrast to ARC LepRb neurons, LepRb PMv neurons represent a relatively uniform population of leptinactivated cells.

\section{Activation of LepRb PMv neurons by sexual odorants}

The previously described activation of some PMv neurons after the presentation of sexual odorants suggested that LepRb PMv neurons might receive both odorant cues and leptin-mediated metabolic signals, thereby integrating this information in a single population of neurons. To determine whether the sexual odorant-responsive PMv neurons overlap with or are distinct from the LepRb neurons in this region, we exposed LepRb ${ }^{\text {EGFP }}$ animals to fresh bedding or bedding soiled by mice of the opposite sex and examined the activity of EGFP-containing LepRb
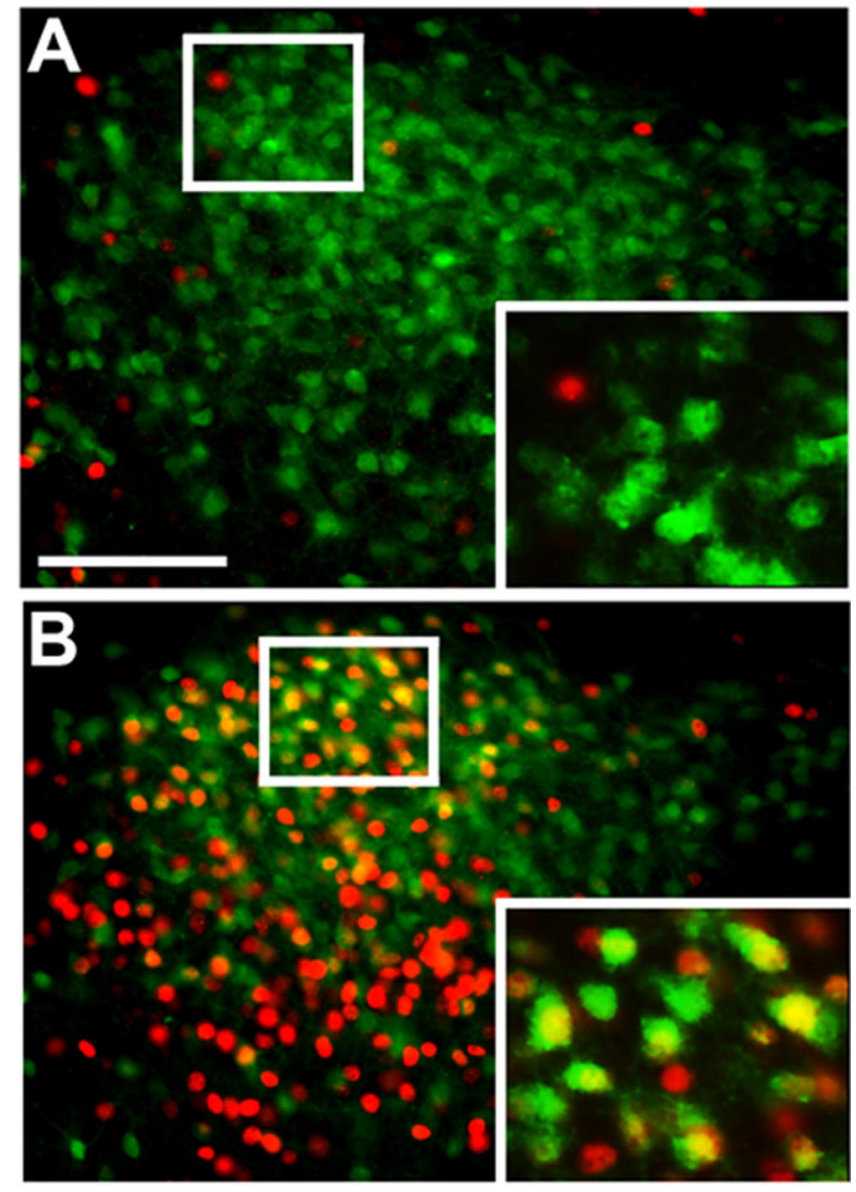

Figure 3. $A, B$, Male or female odors increase Fos-IR in LepRb PMv cells of the opposite sex. Representative images show increased Fos-IR (red, nuclear) in EGFP-IR PMv LepRb cells (green, cytoplasmic) of female LepRb ${ }^{\text {EGFP }}$ mice exposed to opposite sex soiled bedding (B), compared with fresh bedding controls $(\boldsymbol{A})$. Insets represent digital zooms of the indicated area. Scale bar: $100 \mu \mathrm{m}$.

PMv neurons by the criterion of Fos-IR. As previously reported for rats (Yokosuka et al., 1999; Cavalcante et al., 2006a), soiled bedding from mice of the opposite sex increased the number of Fos-IR nuclei in the PMv of both males and females (Fig. 3) (females: fresh, $29 \pm 11, n=3$; soiled, $296 \pm 50, n=3 ; p=0.006$ ) (males: fresh, $51 \pm 29, n=4$; soiled, $156 \pm 23, n=5 ; p=0.02$ ). Fos-IR increased dramatically in LepRb PMv neurons of odorant-exposed compared with fresh-bedding-exposed LepRb ${ }^{\text {EGFP }}$ animals, as well (females: fresh, $3 \pm 2 \%, n=3$; soiled, $44 \pm 2 \%, n=3, p=0.0001$ ) (males: fresh, $4 \pm 2 \%, n=$ 4; soiled, $18 \pm 3 \%, n=5 ; p<0.005)$. Thus, LepRb PMv neurons are activated by metabolic cues via leptin and also by sexual odorant cues.

\section{Projections of PMv LepRb neurons}

Although the overall connectivity of the PMv has been examined previously, LepRb neurons comprise less than half of the total PMv neurons and we thus reasoned that they might exhibit restricted projection patterns compared with the entire PMv. Although using cytoplasmic EGFP expression in LepRb ${ }^{\text {EGFP }}$ mice represents a reliable way to identify LepRb-expressing soma throughout the CNS, it poorly labels the distant projections of LepRb-expressing neurons. We thus generated a novel targeted ROSA26 allele, Gt(ROSA)26Sor ${ }^{\text {EGFPf }}$, in which cre recombinasemediated excision of a transcription-blocking cassette induces 


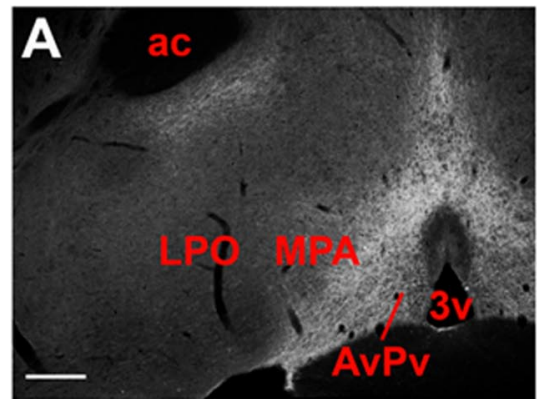

B
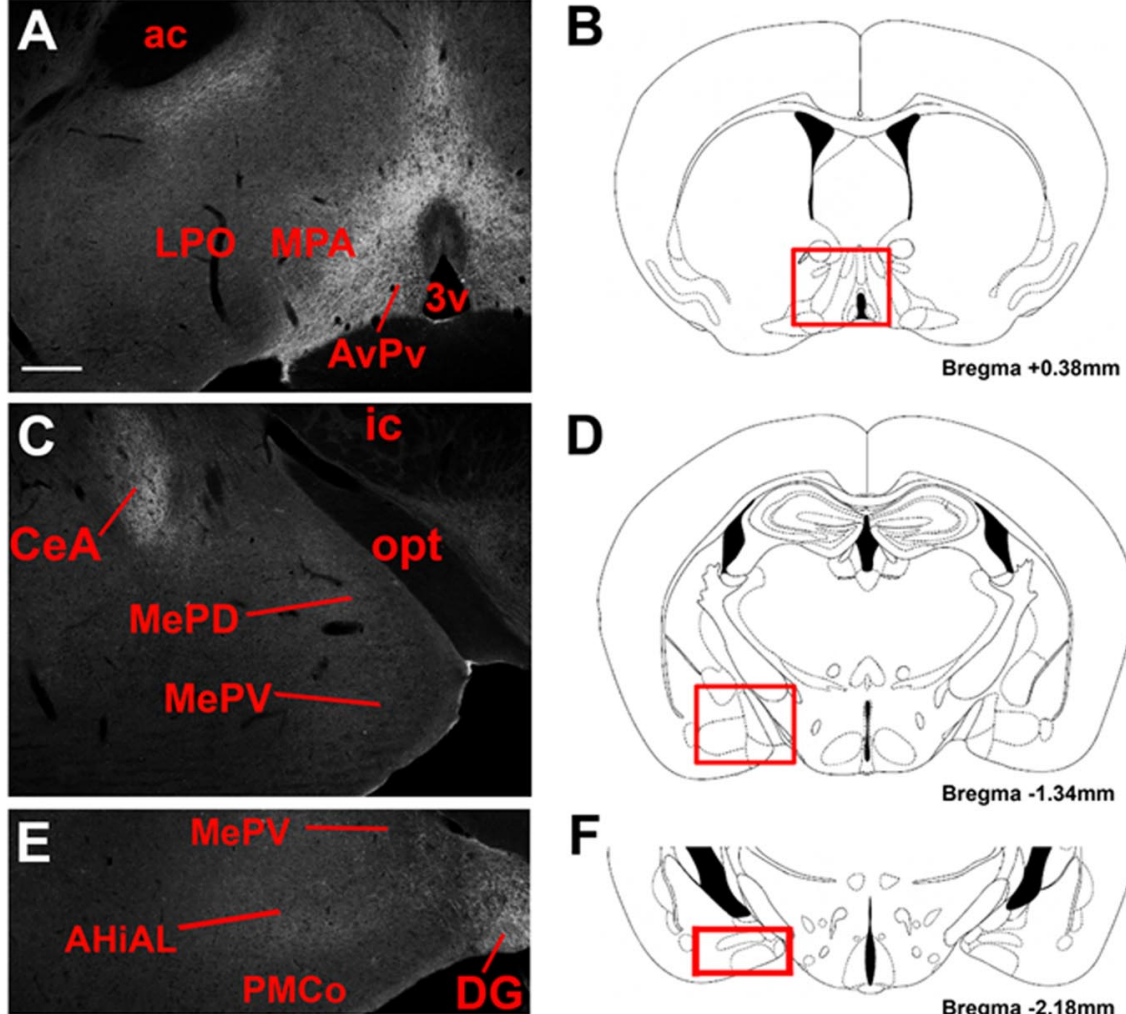

D

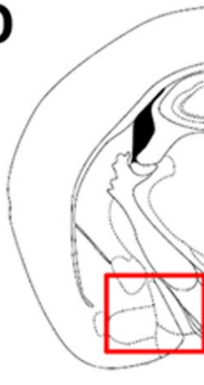

$\mathbf{F}$

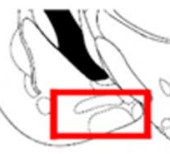

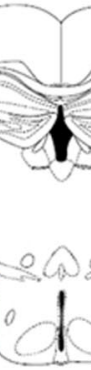

$+7$

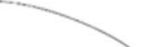

(

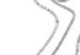

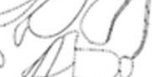

Bregma $-1.34 \mathrm{~mm}$

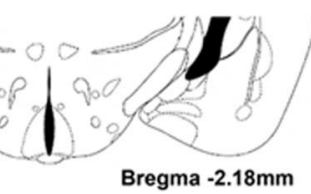

Figure 4. $\quad \boldsymbol{A}-\boldsymbol{F}$, EGFP-IR projections from LepRb neurons to the POA and amygdala in LepRb ${ }^{\text {EGPF }}$ mice. LepRb ${ }^{\text {EGPPf }}$ mice reveal EGFP-IR in POA and AvPv regions ( $A$ ). Although labeling was observed in several amygdaloid regions (including (eA), and the DG, no apparent labeling was observed in medial and posterior amygdaloid regions $(\boldsymbol{C}, \boldsymbol{E})$. Red boxes on reference diagrams $(\boldsymbol{B}, \boldsymbol{D}, \boldsymbol{F})$ indicate comparable atlas sections for POA and amygdala images. Scale bar: $200 \mu \mathrm{m}$. 3v, Third cerebral ventricle; $0 \mathrm{x}$, optic chiasm; opt, optic tract; ac, anterior commissure; ic, internal capsule; MePV, medial amygdala, posteroventral part; AHiAL, amygdalohippocampal area, anterolateral part; PMCo, posteromedial cortical amygdaloid nucleus.

the expression of a farnesylated EGFP (EGFPf) (Fig. 1A); farnesylation drives EGFPf to the membrane, effectively labeling even very long axonal projections (Zylka et al., 2005). We crossed these Gt(ROSA)26Sor ${ }^{E G F P f}$ animals to Lepr ${ }^{\text {cre }}$ mice to generate LepRb ${ }^{\text {EGFPf }}$ mice that express EGFPf in all LepRb neurons to facilitate the study of projections from these neurons.

We used brain sections from the LepRb ${ }^{\mathrm{EGFPf}}$ mice to examine major projection targets of the PMv [the POA and the medial and posterior portions of the amygdala (Canteras et al., 1992)] for EGFP-IR (EGFPf-containing) projections from LepRb neurons (Fig. 4). This examination revealed copious diffuse EGFP-IR in the POA (Fig. $4 A, B$ ), consistent with the dense innervation of this region by LepRb neurons. In contrast, whereas EGFP-IR projections from LepRb neurons were noted in the central nucleus of the amygdala (CeA) and in the nearby dentate gyrus (DG) of the hippocampus, little EGFP-IR was detectable in the medial and posterior portions of the amygdala of the LepRb ${ }^{\text {EGFPf }}$ mice, suggesting few LepRb neurons innervate this region (Fig. $4 C-F)$.

Although these data from LepRb ${ }^{\text {EGFPf }}$ mice reveal the general density of innervation of each region by LepRb neurons, this transgenic approach cannot distinguish the neuroanatomical source of any projections and thus cannot reveal projections specific to the PMv LepRb neurons. To define projections from LepRb-expressing soma in specific brain regions, we used Ad-iZ/ EGFPf, which merges the use of molecular tracers with the creinducible system (for LepRb-specificity) plus adenoviral stereotaxic injection (for anatomic specificity) (Fig. 1A). When transduced into cre-expressing cells, Ad-iZ/EGFPf mediates the expression of EGFPf. Because this is a replicationdefective virus, only the neurons that initially take up this virus at the injection site will be infected. Hence, when Ad-iZ/ EGFPf is injected into the PMv of Lepr ${ }^{\text {cre }}$ mice, EGFPf will be expressed only in LepRb neurons to mediate axonal tracing specifically from PMv LepRb neurons (avoiding tracing from non-LepRb neurons in the PMv).

After the injection of Ad-iZ/EGFPf into the PMv of Lepr ${ }^{\text {cre }}$ mice (Fig. 5A,B), injection sites displayed robust labeling of soma and local processes. No labeling was observed in control (non-cre-expressing) mice (data not shown). In Lepr ${ }^{\text {cre }}$ mice, EGFPf-labeled fibers projected from the LepRb PMv neurons to the POA, including medial and lateral subregions, and AvPv (Fig. 5C,D). The appearance of bouton-like varicosities along labeled fibers in the POA and AvPv suggested the presence of synapses in these regions (Fig. $5 C$, see inset). Although some labeled fibers fell within the ventral border of the bed nucleus of the stria terminalis (BST), we did not detect significant projections from LepRb PMv neurons into the BST/ST or the amygdala (Fig. $5 E, F$ ). Thus, these results suggest that LepRb PMv neurons project primarily to the $\mathrm{POA}$, and poorly innervate the amygdala. Hence, LepRb $\mathrm{PMv}$ neurons densely innervate a subset of the regions innervated by the total population of PMv neurons, and the LepRb PMv neurons may mediate a specific subset of $\mathrm{PMv}$ functions.

Given the novelty of these EGFPf-based tracing systems, we used Fluorogold (FG) to perform retrograde tracing from the POA and MeA to confirm the LepRb PMv $\rightarrow$ POA circuitry as well as the paucity of LepRb PMv $\rightarrow$ MeA connections (Fig. 6). We treated C57BL/6J mice with leptin for $2 \mathrm{~h}$ before perfusion to examine the potential colocalization of pSTAT3 in LepRb PMv neurons with the retrograde accumulation of FG from POA regions (Fig. $6 A-C$ ). Copious colocalization, visible as cytoplasmic FG around nuclear pSTAT3-IR was observed in the PMv of the animals examined (Fig. 6C), confirming the projection of LepRb $\mathrm{PMv}$ neurons into the POA. We additionally injected LepRb ${ }^{\mathrm{EGFP}}$ animals with FG into the MeA (Fig. 6D-F). FG-IR cells were observed in ipsilateral regions of the accessory olfactory bulb (data not shown), confirming that the targeted amygdala regions lie within the olfactory pathway. Although FG-labeled PMv cells were observed after the injection of FG into the MeA (Fig. 6F), these did not colocalize with EGFP-IR LepRb neurons (note that both labels are cytoplasmic, in this case). Overall, these data confirm that LepRb PMv neurons project rostrally to innervate the $\mathrm{POA}$, but poorly innervate other PMv projection targets, such as the MeA.

\section{LepRb PMv neurons synapse with GnRH neurons}

Although EGFPf- and FG-mediated tract tracing do not permit the identification of synaptic contacts, the projection of LepRb 
PMv neurons to brain regions containing GnRH neurons and the importance of the $\mathrm{PMv}$ for odorant-dependent $\mathrm{LH}$ release (Beltramino and Taleisnik, 1985) led us to hypothesize that LepRb PMV neurons directly innervate $\mathrm{GnRH}$ neurons. We therefore used a transgenic mouse line ("BIG") that expresses the trans-synaptic tracer, barley lectin, along with EGFP, in GnRH neurons, and which thus reveals the synaptic contacts of GnRH neurons by their accumulation of barley lectin [detected by immunoreactivity for the closely related lectin, wheat germ agglutinin (WGA)] (Boehm et al., 2005). The analysis of BIG mice revealed a large population of $\mathrm{PMv}$ neurons positive for WGA-IR and thus in synaptic contact with GnRH neurons (Fig. 7) (Boehm et al., 2005). The absence of GnRH-IR axonal fibers in the PMv reveals that these WGA-IR PMv neurons lie afferent to (as opposed to efferent of) $\mathrm{GnRH}$ neurons (Boehm et al., 2005) (data not shown). To examine whether and which LepRb neurons might synapse directly onto GnRH neurons, we treated BIG mice with leptin $(5 \mathrm{mg} / \mathrm{kg}$ i.p., $1 \mathrm{~h}$ ) to determine the potential colocalization of cytoplasmic WGA-IR around pSTAT3-IR nuclei in the PMv (Fig. 7A). This analysis revealed that many WGA-IR PMv neurons in these animals express LepRb by the criterion of leptin-stimulated pSTAT3-IR, and conversely, that many pSTAT3-IR LepRb neurons in the PMv contain WGA-IR. No WGA-IR was detected in nontransgenic animals (Fig. 7B). Thus, LepRb PMv neurons not only project to the POA/AvPv, but many LepRb PMv neurons synapse directly on GnRH neurons.

\section{Discussion}

Prioritization of physiological functions based on energy availability requires continuous processing of inputs as to the status of the body and environment. In 1974, Frisch and McArthur proposed the "critical weight hypothesis," linking energy stores to fertility by suggesting that a threshold level of body fat is required in order for females to achieve menarche and to maintain normal ovulatory cycles (Frisch and McArthur, 1974). Indeed, in normal weight women, a $10-15 \%$ decrease in body weight results in the interruption of normal ovulation and menstrual cycles due to decreased GnRH secretion by the hypothalamus (hence, "hypothalamic amenorrhea") (Pirke et al., 1985; Bronson and Manning, 1991; Loucks et al., 1998). Since these early studies, much progress has been made in detailing mechanisms controlling the reproductive axis and energy balance individually, although the mechanisms by which these systems are integrated have remained unclear. Leptin acts via LepRb in the brain to regulate energy balance and reproduction, suggesting that LepRb-expressing neurons link fat mass and reproductive competence (Ahima et al., 1996; Chehab et al., 1996; Bates et al., 2003).

One substantial population of LepRb-expressing cells lies in the PMv, a region known to contain gonadal steroid receptors and to be activated by mating and sexual sensory inputs, as well as leptin, thus representing a potential site for the integration of reproductive and metabolic cues (Simerly et al., 1990; Pfaus et al., 1993; Kollack-Walker and Newman, 1995; Coolen et al., 1996; Osterlund et al., 1998; Yokosuka et al., 1999; Veening et al., 2005; Cavalcante et al., 2006a). Although the PMv as a whole has been investigated to some extent, the LepRb-expressing subpopulation of PMv neurons has remained little-studied.

Utilizing LepRb ${ }^{\text {EGFP }}$ mice (which express EGFP specifically in LepRb-expressing cells) combined with leptin-stimulated pSTAT3-IR, we confirmed the previously reported presence of functional LepRb in a subset of PMv cells. Although previous studies have also demonstrated increased Fos-IR in the PMv after leptin administration (Elias et al., 2000), the EGFP expression of LepRb neurons in the LepRb ${ }^{\text {EGFP }}$ animals enabled us to examine the regulation of the LepRb PMv neurons specifically. We showed the colocalization of leptin-stimulated Fos-IR specifically in PMv LepRb neurons, and that leptin activates the majority of LepRb PMv neurons by this criterion. Direct electrophysiologic recordings from LepRb $\mathrm{PMv}$ neurons revealed the leptinstimulated depolarization of a similarly high percentage of these cells in acute slice preparations as was observed by Fos-IR in vivo. This leptin-stimulated depolarization was independent of transmission by a variety of amino acid neurotransmitters. Thus, these 

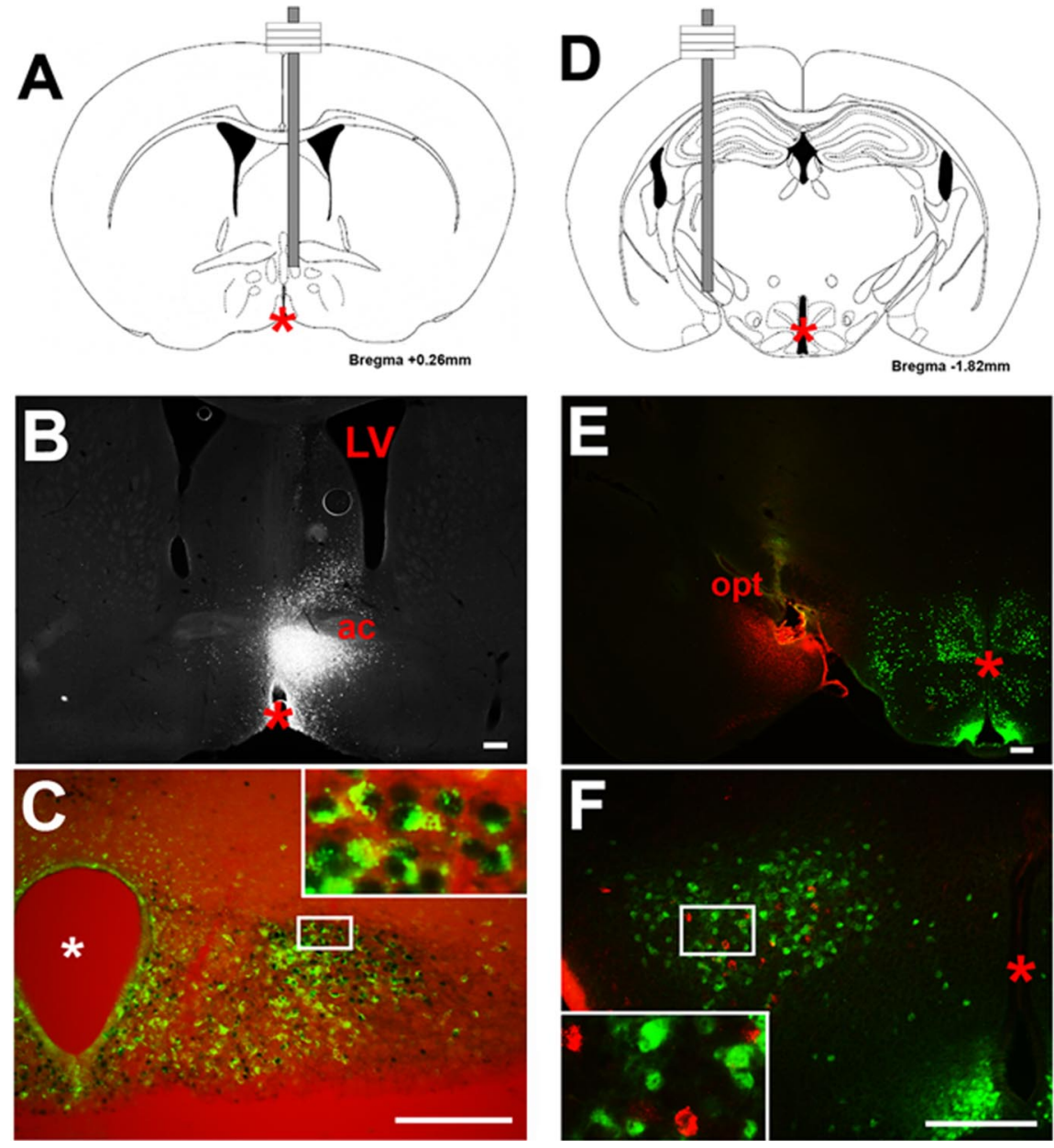

Figure 6. $\boldsymbol{A}-\boldsymbol{F}$, Retrograde tracing of inputs from LepRb PMv cells. Injection of FG into the POA of $C 57 \mathrm{BL} / 6 \mathrm{~J}$ mice revealed tracer plumes in the POA $(\boldsymbol{B})$. Retrogradely traced, FG-IR (green, cytoplasmic) was detected around leptin-induced pSTAT3-IR (black, nuclear) in the PMv (C). Conversely, injection of FG into the MeA of LepRb ${ }^{\text {EGFP }}$ mice revealed tracer plumes in MeA $(\boldsymbol{E})$ (red), but no colocalization of PMv FG-IR cells (red) with EGFP-IR LepRb cells (green) $(\boldsymbol{F})$. Coronal diagrams indicate POA and MeA injection sites $(\boldsymbol{A}, \boldsymbol{D})$. Insets show high magnification of colocalization. Scale bars: $100 \mu \mathrm{m}$. Asterisks label third cerebral ventricle. LV, Lateral ventricle; ac, anterior commissure; opt, optic tract. Diagrams adapted from Paxinos and Franklin (2001).
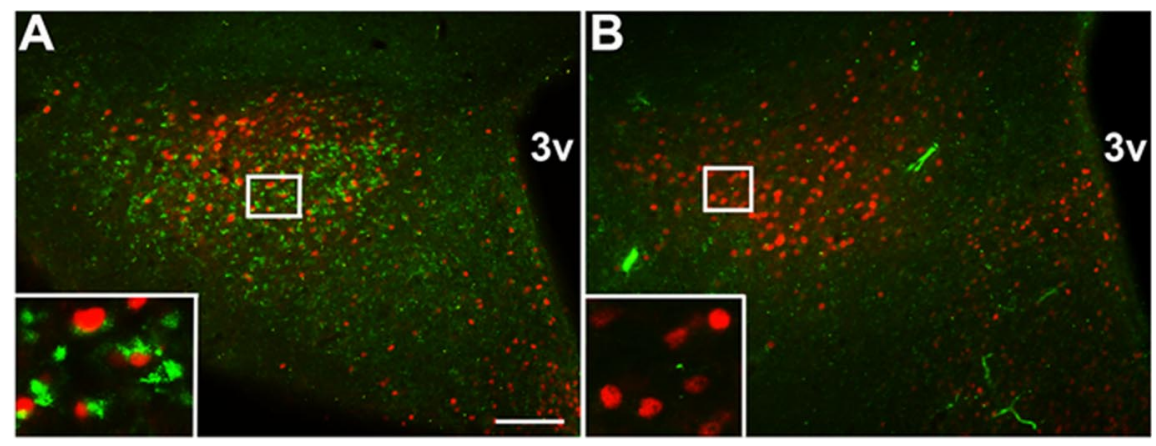

Figure 7. $\boldsymbol{A}, \boldsymbol{B}$, Retrograde tracing of inputs to $\mathrm{GnRH}$ neurons from leptin-responsive PMv cells in BIG mice. Female BIG mice were administered $5 \mathrm{mg} / \mathrm{kg}$ leptin i.p. for $1 \mathrm{~h}$. Representative images show colocalization of the transsynaptic tracer BL (WGA-IR, green, cytoplasmic) around leptin-induced pSTAT3-IR (red, nuclear) in the PMv of BIG mice (A). No WGA-IR was detected in leptin-treated control mice $(\boldsymbol{B})$. Insets show high magnification of colocalized BL and pSTAT3. Scale bar: $100 \mu \mathrm{m} ; 3 \mathrm{v}$, third cerebral ventricle.

data demonstrate that leptin activates LepRb PMv neurons by direct action.

Previous studies of Fos-IR have revealed PMv activation after mating and estrogen or progesterone stimulation (with females responding to a greater degree) (Coolen et al., 1996), as well as in response to odorant-containing bedding soiled by the opposite sex (Yokosuka et al., 1999; Cavalcante et al., 2006a). These and other studies have placed the PMv behind both MeA and BST, but before the GnRH neurons in the POA in the sequence of stimulation beginning with sexual odorants and ending in rise of serum LH (Beltramino and Taleisnik, 1985; Yokosuka et al., 1999; Yoon et al., 2005; Cavalcante et al., 2006a; Dulac and Wagner, 2006). Consistent with these previous reports in rats, Fos-IR increases in the PMv of both male and female mice exposed to opposite sexderived odors in soiled bedding; this included a substantial population of LepRb PMv neurons, revealing the integration of odorant and metabolic (leptin) cues by these neurons (Fig. 8). Although we additionally observed soiled beddingstimulated Fos-IR in other regions within the vomeronasal circuit, including the MeA, we did not detect the induction of Fos-IR in LepRb neurons elsewhere in the brain (data not shown), suggesting that LepRb PMv neurons represent the unique site for the integration of sexual odorant cues with leptin-mediated signals of energy balance.

To gain some insight into the potentially unique functions of the LepRb PMv neurons, we used two novel cre-inducible EGFPf-dependent tracing systems to examine projections from LepRb neurons into $\mathrm{PMv}$ projection targets. Previous tracing studies that examined the overall population of PMv neurons identified ascending projections to the POA and $\mathrm{AvPv}$, and to the medial and posterior portions of the amygdala (Canteras et al., 1992). EGFPfcontaining projections from transgenelabeled LepRb neurons in LepRb ${ }^{\text {EGFPf }}$ mice revealed dense projections into the $\mathrm{POA} / \mathrm{AvPv}$ and a few regions of the amygdala [including the CeA, which is not innervated by the PMv (Canteras et al., 1992)], but showed sparse innervation of the medial and posterior aspects of the amygdala that are targets of some PMv neurons. Indeed, Ad-iZ/EGFPf-mediated tracing specifically from LepRb PMv neurons revealed their projection to the preoptic region, including the $\mathrm{POA}$ and $\mathrm{AvPv}$. In each of the regions with labeled processes, the appearance of varicosities/boutons suggested synapses at these locations. Although a few LepRb PMv neurons projected to the ventral BST, these neurons did not significantly innervate the amygdala. Similarly, whereas retrograde tracer applied to the POA accumulated in LepRb PMv neurons, these LepRb neurons did not accumulate retrograde tracer from the MeA.

Thus, LepRb PMv neurons contribute to a specific subset of 
the circuitry of the larger PMv, and LepRb PMv cells may thus participate in only a portion of PMv functions. The MeA processes sexual olfactory cues before relaying them to areas including the PMv, and the absence of projections from the LepRb PMv neurons to the MeA suggests that the LepRb PMv neurons receive odorant information, integrate it with metabolic information, and relay it forward to regions that govern reproduction, but do not contribute to the processing of pheromonal signals in the MeA itself. LepRb PMv neurons are thus well positioned to integrate sensory sexual and hormonal metabolic cues, and could function to regulate the reproductive axis based on availability of food and mates.

Indeed, our data using leptin-treated BIG mice demonstrate LepRb PMv cells lying upstream of $\mathrm{GnRH}$ neurons. Given the function of the PMv in integrating sexual odorant cues and the projection of LepRb PMv neurons to the POA, and specifically to GnRH neurons, along with the reported glutamatergic nature of the PMv (Kocsis et al., 2003), we hypothesize that these cells might function to integrate sexual cues with the leptin-mediated signal of energy status (Fig. 8). Other mechanisms, including the regulation of kisspeptincontaining neurons by leptin (Smith et al., 2006; Castellano et al., 2009), could also contribute to the metabolic regulation of reproduction. Future studies will be necessary to fully characterize the specific physiological roles of leptin in these circuits.

\section{References}

Ahima RS, Prabakaran D, Mantzoros C, Qu D, Lowell B, Maratos-Flier E, Flier JS (1996) Role of leptin in the neuroendocrine response to fasting. Nature 382:250-252.

Ahima RS, Dushay J, Flier SN, Prabakaran D, Flier JS (1997) Leptin accelerates the onset of puberty in normal female mice. J Clin Invest 99:391-395.

Banks AS, Davis SM, Bates SH, Myers MG Jr (2000) Activation of downstream signals by the long form of the leptin receptor. J Biol Chem 275:14563-14572.

Bates SH, Stearns WH, Dundon TA, Schubert M, Tso AW, Wang Y, Banks AS, Lavery HJ, Haq AK, Maratos-Flier E, Neel BG, Schwartz MW, Myers MG $\operatorname{Jr}$ (2003) STAT3 signaling is required for leptin regulation of energy balance but not reproduction. Nature 421:856-859.

Beltramino C, Taleisnik S (1985) Ventral premammillary nuclei mediate pheromonal-induced LH release stimuli in the rat. Neuroendocrinology 41:119-124.

Berthoud HR (2007) Interactions between the "cognitive" and "metabolic" brain in the control of food intake. Physiol Behav 91:486-498.

Boehm U, Zou Z, Buck LB (2005) Feedback loops link odor and pheromone signaling with reproduction. Cell 123:683-695.

Bronson FH, Manning JM (1991) The energetic regulation of ovulation: a realistic role for body fat. Biol Reprod 44:945-950.

Burcelin R, Thorens B, Glauser M, Gaillard RC, Pralong FP (2003) Gonadotropin-releasing hormone secretion from hypothalamic neurons: stimulation by insulin and potentiation by leptin. Endocrinology 144:4484-4491.

Canteras NS, Simerly RB, Swanson LW (1992) Projections of the ventral premammillary nucleus. J Comp Neurol 324:195-212.

Canteras NS, Simerly RB, Swanson LW (1995) Organization of projections from the medial nucleus of the amygdala: a PHAL study in the rat. J Comp Neurol 360:213-245.

Castellano JM, Roa J, Luque RM, Dieguez C, Aguilar E, Pinilla L, TenaSempere M (2009) KiSS-1/kisspeptins and the metabolic control of re- production: physiologic roles and putative physiopathological implications. Peptides 30:139-145.

Cavalcante JC, Bittencourt JC, Elias CF (2006a) Female odors stimulate CART neurons in the ventral premammillary nucleus of male rats. Physiol Behav 88:160-166.

Cavalcante JC, Sita LV, Mascaro MB, Bittencourt JC, Elias CF (2006b) Distribution of urocortin 3 neurons innervating the ventral premammillary nucleus in the rat brain. Brain Res 1089:116-125.

Chehab FF, Lim ME, Lu R (1996) Correction of the sterility defect in homozygous obese female mice by treatment with the human recombinant leptin. Nat Genet 12:318-320.

Cohen P, Zhao C, Cai X, Montez JM, Rohani SC, Feinstein P, Mombaerts P, Friedman JM (2001) Selective deletion of leptin receptor in neurons leads to obesity. J Clin Invest 108:1113-1121.

Coolen LM, Peters HJ, Veening JG (1996) Fos immunoreactivity in the rat brain following consummatory elements of sexual behavior: a sex comparison. Brain Res 738:67-82.

Cowley MA, Smart JL, Rubinstein M, Cerdán MG, Diano S, Horvath TL, Cone RD, Low MJ (2001) Leptin activates anorexigenic POMC neurons through a neural network in the arcuate nucleus. Nature 411:480-484.

de Luca C, Kowalski TJ, Zhang Y, Elmquist JK, Lee C, Kilimann MW, Ludwig T, Liu SM, Chua SC Jr (2005) Complete rescue of obesity, diabetes, and infertility in $\mathrm{db} / \mathrm{db}$ mice by neuron-specific LEPR-B transgenes. J Clin Invest 115:3484-3493.

De Souza MJ, Miller BE, Loucks AB, Luciano AA, Pescatello LS, Campbell CG, Lasley BL (1998) High frequency of luteal phase deficiency and anovulation in recreational women runners: blunted elevation in folliclestimulating hormone observed during luteal-follicular transition. J Clin Endocrinol Metab 83:4220-4232.

Dhillon H, Zigman JM, Ye C, Lee CE, McGovern RA, Tang V, Kenny CD, Christiansen LM, White RD, Edelstein EA, Coppari R, Balthasar N, Cowley MA, Chua S Jr, Elmquist JK, Lowell BB (2006) Leptin directly activates $\mathrm{SF} 1$ neurons in the $\mathrm{VMH}$, and this action by leptin is required for normal body-weight homeostasis. Neuron 49:191-203.

Dulac C, Wagner S (2006) Genetic analysis of brain circuits underlying pheromone signaling. Annu Rev Genet 40:449-467.

Elias CF, Aschkenasi C, Lee C, Kelly J, Ahima RS, Bjorbaek C, Flier JS, Saper CB, Elmquist JK (1999) Leptin differentially regulates NPY and POMC neurons projecting to the lateral hypothalamic area. Neuron 23:775-786.

Elias CF, Kelly JF, Lee CE, Ahima RS, Drucker DJ, Saper CB, Elmquist JK (2000) Chemical characterization of leptin-activated neurons in the rat brain. J Comp Neurol 423:261-281.

Elmquist JK, Ahima RS, Maratos-Flier E, Flier JS, Saper CB (1997) Leptin 
activates neurons in ventrobasal hypothalamus and brainstem. Endocrinology 138:839-842.

Elmquist JK, Bjørbaek C, Ahima RS, Flier JS, Saper CB (1998) Distributions of leptin receptor mRNA isoforms in the rat brain. J Comp Neurol 395:535-547.

Elmquist JK, Elias CF, Saper CB (1999) From lesions to leptin: hypothalamic control of food intake and body weight. Neuron 22:221-232.

Elmquist JK, Coppari R, Balthasar N, Ichinose M, Lowell BB (2005) Identifying hypothalamic pathways controlling food intake, body weight, and glucose homeostasis. J Comp Neurol 493:63-71.

Farooqi IS, Jebb SA, Langmack G, Lawrence E, Cheetham CH, Prentice AM, Hughes IA, McCamish MA, O'Rahilly S (1999) Effects of recombinant leptin therapy in a child with congenital leptin deficiency. N Engl J Med 341:879-884.

Friedman JM (2002) The function of leptin in nutrition, weight, and physiology. Nutr Rev 60:S1-S14.

Frisch RE, McArthur JW (1974) Menstrual cycles: fatness as a determinant of minimum weight for height necessary for their maintenance or onset. Science 185:949-951.

Gao Q, Horvath TL (2007) Neurobiology of feeding and energy expenditure. Annu Rev Neurosci 30:367-398.

Gelling RW, Morton GJ, Morrison CD, Niswender KD, Myers MG Jr, Rhodes CJ, Schwartz MW (2006) Insulin action in the brain contributes to glucose lowering during insulin treatment of diabetes. Cell Metab 3:67-73.

Gonzalez LC, Pinilla L, Tena-Sempere M, Aguilar E (1999) Leptin(116130) stimulates prolactin and luteinizing hormone secretion in fasted adult male rats. Neuroendocrinology 70:213-220.

Gruaz NM, Lalaoui M, Pierroz DD, Englaro P, Sizonenko PC, Blum WF, Aubert ML (1998) Chronic administration of leptin into the lateral ventricle induces sexual maturation in severely food-restricted female rats. J Neuroendocrinol 10:627-633.

Hahn JD, Coen CW (2006) Comparative study of the sources of neuronal projections to the site of gonadotrophin-releasing hormone perikarya and to the anteroventral periventricular nucleus in female rats. J Comp Neurol 494:190-214.

He TC, Zhou S, da Costa LT, Yu J, Kinzler KW, Vogelstein B (1998) A simplified system for generating recombinant adenoviruses. Proc Natl Acad Sci U S A 95:2509-2514.

Hommel JD, Trinko R, Sears RM, Georgescu D, Liu ZW, Gao XB, Thurmon JJ, Marinelli M, DiLeone RJ (2006) Leptin receptor signaling in midbrain dopamine neurons regulates feeding. Neuron 51:801-810.

Kocsis K, Kiss J, Csáki A, Halász B (2003) Location of putative glutamatergic neurons projecting to the medial preoptic area of the rat hypothalamus. Brain Res Bull 61:459-468.

Kollack-Walker S, Newman SW (1995) Mating and agonistic behavior produce different patterns of Fos immunolabeling in the male Syrian hamster brain. Neuroscience 66:721-736.

Leshan RL, Björnholm M, Münzberg H, Myers MG Jr (2006) Leptin receptor signaling and action in the central nervous system. Obesity (Silver Spring) 14 [Suppl 5]:208S-212S.

Li C, Vaughan J, Sawchenko PE, Vale WW (2002) Urocortin IIIimmunoreactive projections in rat brain: partial overlap with sites of type 2 corticotrophin-releasing factor receptor expression. J Neurosci 22:991-1001.

Loucks AB, Verdun M, Heath EM (1998) Low energy availability, not stress of exercise, alters LH pulsatility in exercising women. J Appl Physiol 84:37-46.

Mao X, Fujiwara Y, Orkin SH (1999) Improved reporter strain for monitoring cre recombinase-mediated DNA excisions in mice. Proc Natl Acad Sci U S A 96:5037-5042.

Marsteller FA, Lynch CB (1987) Reproductive responses to variation in temperature and food supply by house mice. I. Mating and pregnancy. Biol Reprod 37:838-843.

Morton GJ, Cummings DE, Baskin DG, Barsh GS, Schwartz MW (2006) Central nervous system control of food intake and body weight. Nature 443:289-295.

Münzberg H, Huo L, Nillni EA, Hollenberg AN, Bjørbaek C (2003) Role of signal transducer and activator of transcription 3 in regulation of hypothalamic proopiomelanocortin gene expression by leptin. Endocrinology 144:2121-2131.
Myers MG Jr (2004) Leptin receptor signaling and the regulation of mammalian physiology. Recent Prog Horm Res 59:287-304.

Nagatani S, Guthikonda P, Thompson RC, Tsukamura H, Maeda KI, Foster DL (1998) Evidence for GnRH regulation by leptin: leptin administration prevents reduced pulsatile LH secretion during fasting. Neuroendocrinology 67:370-376.

Oral EA, Simha V, Ruiz E, Andewelt A, Premkumar A, Snell P, Wagner AJ, DePaoli AM, Reitman ML, Taylor SI, Gorden P, Garg A (2002) Leptinreplacement therapy for lipodystrophy. N Engl J Med 346:570-578.

Osterlund M, Kuiper GG, Gustafsson JA, Hurd YL (1998) Differential distribution and regulation of estrogen receptor- $\alpha$ and $-\beta$ mRNA within the female rat brain. Mol Brain Res 54:175-180.

Paxinos G, Franklin KBJ (2001) The mouse brain in stereotaxic coordinates. San Diego: Academic.

Pfaus JG, Kleopoulos SP, Mobbs CV, Gibbs RB, Pfaff DW (1993) Sexual stimulation activates $\mathrm{c}$-fos within estrogen-concentrating regions of the female rat forebrain. Brain Res 624:253-267.

Pirke KM, Schweiger U, Lemmel W, Krieg JC, Berger M (1985) The influence of dieting on the menstrual cycle of healthy young women. J Clin Endocrinol Metab 60:1174-1179.

Rondini TA, Baddini SP, Sousa LF, Bittencourt JC, Elias CF (2004) Hypothalamic cocaine- and amphetamine-regulated transcript neurons project to areas expressing gonadotropin releasing hormone immunoreactivity and to the anteroventral periventricular nucleus in male and female rats. Neuroscience 125:735-748.

Schneider JE, Goldman MD, Tang S, Bean B, Ji H, Friedman MI (1998) Leptin indirectly affects estrous cycles by increasing metabolic fuel oxidation. Horm Behav 33:217-228.

Schwartz MW, Woods SC, Porte D Jr, Seeley RJ, Baskin DG (2000) Central nervous system control of food intake. Nature 404:661-671.

Shimomura I, Hammer RE, Ikemoto S, Brown MS, Goldstein JL (1999) Leptin reverses insulin resistance and diabetes mellitus in mice with congenital lipodystrophy. Nature 401:73-76.

Simerly RB, Chang C, Muramatsu M, Swanson LW (1990) Distribution of androgen and estrogen receptor mRNA-containing cells in the rat brain: an in situ hybridization study. J Comp Neurol 294:76-95.

Smith JT, Acohido BV, Clifton DK, Steiner RA (2006) KiSS-1 neurones are direct targets for leptin in the ob/ob mouse. J Neuroendocrinol 18:298-303.

Smith MA, Hisadome K, Al-Qassab H, Heffron H, Withers DJ, Ashford ML (2007) Melanocortins and agouti-related protein modulate the excitability of two arcuate nucleus neuron populations by alteration of resting potassium conductances. J Physiol 578:425-438.

Soliman GA, Ishida-Takahashi R, Gong Y, Jones JC, Leshan RL, Saunders TL, Fingar DC, Myers MG Jr (2007) A simple qPCR-based method to detect correct insertion of homologous targeting vectors in murine ES cells. Transgenic Res 16:665-670.

Srinivas S, Watanabe T, Lin CS, William CM, Tanabe Y, Jessell TM, Costantini F (2001) Cre reporter strains produced by targeted insertion of EYFP and ECFP into the ROSA26 locus. BMC Dev Biol 1:4.

Sullivan SD, Howard LC, Clayton AH, Moenter SM (2002) Serotonergic activation rescues reproductive function in fasted mice: does serotonin mediate the metabolic effects of leptin on reproduction? Biol Reprod 66:1702-1706.

Veening JG, Coolen LM, de Jong TR, Joosten HW, de Boer SF, Koolhaas JM, Olivier B (2005) Do similar neural systems subserve aggressive and sexual behaviour in male rats? Insights from c-Fos and pharmacological studies. Eur J Pharmacol 526:226-239.

White DW, Kuropatwinski KK, Devos R, Baumann H, Tartaglia LA (1997) Leptin receptor (OB-R) signaling. J Biol Chem 272:4065-4071.

Yokosuka M, Matsuoka M, Ohtani-Kaneko R, Iigo M, Hara M, Hirata K, Ichikawa M (1999) Female-soiled bedding induced fos immunoreactivity in the ventral part of the premammillary nucleus (PMv) of the male mouse. Physiol Behav 68:257-261.

Yoon H, Enquist LW, Dulac C (2005) Olfactory inputs to hypothalamic neurons controlling reproduction and fertility. Cell 123:669-682.

Zylka MJ, Rice FL, Anderson DJ (2005) Topographically distinct epidermal nociceptive circuits revealed by axonal tracers targeted to Mrgprd. Neuron $45: 17-25$. 